\title{
Transformation of Social and Labor Relations and Human Resource Management in the Context of the Pandemic
}

\author{
Pavel Simonin ${ }^{1}$, Anastasia Rudnitskaya ${ }^{1},{ }^{*}$ Valery Yudaev $^{1}$, Mikhail Makovetsky $^{1}$, \\ Sofya Blagova ${ }^{1}$
}

${ }^{1}$ Moscow University named after S.Yu. Witte, Russia

*Email: arudnitskaya@muiv.ru

\begin{abstract}
The transformation of social and labour relations will allow for a new order in the market environment of the subjects of labour relations and create a reasonable transition model that will ensure universal agreement between the participants of labour relations. The social and regional gap associated with the demographic situation, digitalization, lack of skills and non-compliance with modern challenges, the development of artificial intelligence, determine the nature of the institutional structure of labour relations and motives for income generation. In the face of cumulative shocks, wages are adjusted extremely slowly and disproportionately. The study showed the presence of "inequality traps" and/or "middle income traps", which can be leveled on the basis of the mechanism of "built-in stabilizer" of the institutional structure of labour relations. At the same time, the applied technologies for the use of human resources of the organization should be aimed at increasing labour productivity and GDP, which mitigate the shocks caused by exogenous determinants due to the transition of organizations to complex adaptive systems that amortize the consequences of cyclical unemployment. The analysis showed that the average per capita actual income during the epidemic in Russia had a significant discrepancy with the forecast values and fell by $17.2 \%$. At the same time, there is a direct correlation between GDP at purchasing power parity and household income. A policy of social support and consolidation of the balance of jobs and firms carried out since the beginning of the pandemic in Russia, will allow to recover faster after lifting of restrictions, in particular, on the basis of employment and the development of industry responsive training programs, will favor the stabilization of the achieved balance in the demographic sphere. At the same time, the development of digitalization will contribute to an increase in GDP per capita and income of the population of Russia as a whole.
\end{abstract}

Keywords: Transformation, Wages, Income, Social and labour relations, Demography, Economic reforms, Pandemic, Digitalization.

\section{INTRODUCTION}

The transformation of social and labour relations as an important part of the transition to more complex adaptive systems during the COVID-19 virus pandemic, which has catastrophic destructive and demographic consequences, determines a new level of interaction between the subjects of labour relations, which will prevent anarchy in conditions of crisis and social irresponsibility. Despite the fact that organizations conducting social dialogue have the right to create various forms of representatives, fundamental issues remain open that have not been resolved between principals and agents in the context of the emerging prerequisites of instability, recession and cyclical downturns in the economy. The purpose of this article is to assess the impact of the transformation of social and labour relations on the qualitative and quantitative indicators of income of the population in the aspect of human resource management during the pandemic. Based on the results of the transformation of social and labour relations, it will be possible to re-organize the market environment of the subjects of labour relations and create a reasonable transition model that will ensure 
universal agreement between the participants of labour relations. The new paradigm of labour relations will allow us to determine the structural and innovative transformation through which organizations will quickly respond and adapt to market conditions and exogenous factors.

\section{RESEARCH METHODOLOGY}

This study uses a two-part methodology. First of all, there was used a systematic approach in its most general form, when the transformation of social and labour relations was considered taking into account the feedback effects of GDP on the income of the population of Russia based on the selection factor and effective signs, the collection of statistical material, its testing, studying relationships using graphs and analytical groups, the evaluation of the results. At the same time, the system was expressed in the fact that the problem was presented structurally based on the relationship with external determinants. Secondly, an institutional approach was used and it is shown that the process of transformation of social and labour relations appears as a set of several parallel and multidirectional processes between the principal and the agent, which form a new institutional paradigm and formal "rules of the game", mechanisms that ensure their implementation.

\section{RESEARCH RESULTS}

The gradual liberalization of the business environment in post-communist countries, with an emphasis on removing barriers and facilitating entrepreneurship, has led to a number of changes in the employer - employee status [1]. This is especially true of changes in social and labour relations in Russia after 1990 [2].

The report of the global commission of the International labour organization on the future of work, entitled "Working for a brighter future", lists various challenges that threaten the well-being, employment prospects and security of the entire population. Such relations more than ever require solidarity, which is increasingly advocated by modern trade unions [3]. It should be noted that the concept of solidarity, which represents "joint actions, support and retention of initiatives to address specific issues in the enterprise and the industry as a whole" [4] will remain to some extent unchanged until the system of social and labour relations is transformed. In connection with this, the problem of "social stratification of society" is also traced [5].

Other arguments in favor of the transformation of labour relations has the work of J. McMillan and C. Woodruff, who drew attention to the speed of transformation of markets, which "developed spontaneously in each country with a transition economy" and therefore changed the nature of the institutional structure of labour relations [6].

As a result, the process of transformation of social and labour relations is increasingly clearly taking on the features of a consistent (or spontaneous) transition from one state of the system to another, which provides a new level of equilibrium. Therefore, "labour relations have a direct impact on the labour market, determining the direction of decision-making in organizations, as well as on the governments of individual countries" [7].

The most significant and important explanation here is why in most countries "we cannot exist except by buying goods on the market with the income that we receive." This system works as long as each member of the community has a strong motive for generating income." [8] That's why S. Shapiro and J. Stiglitz pointed out that "wages are adjusted exceptionally slowly in the process of cumulative shocks. In this discourse, the incentives for creative work are significantly undermined by the very fact that there is an "inequality trap" and/or a "middle income trap" [9].

The decline in demand for labour will ultimately lead to a reduction in wages and an increase in the unemployment rate. However, during the transition period, "the decline in earnings will correspond to the parameters of unemployment growth, which can be a rather slow process" [10].

For example, during the transition period in Russia, "a special characteristic has developed: the dominance of extremely high variability in the level of wages with relative stability of employment" [11].

In this process of transformation the so-called factors of economic growth of "the investment in human capital and increased investment in research and development" specified by the Nobel Laureate in Economics P. Romer work [12]. Epidemiological shocks can be stabilized on the basis of institutional transformation of social and labour relations, so the "built-in stabilizer" of the institutional structure of labour relations is a socio-economic mechanism that mitigates shocks caused by exogenous determinants due to the transition of organizations to complex adaptive systems that amortize the consequences of cyclical unemployment.

The positive experience of institutionalization of labour relations may be observed in Sweden and parliamentary policy in Denmark [13]. These countries have actively applied the tools of broad coverage of enterprises by collective agreements and improvement of the production system.

A. G. Aganbegyan, the academician of the Russian Academy of Sciences noted: "Effective income policy is not only the result of accelerated economic growth, but 
also the most important driver of its development. According to the Institute for Research and Expertise of the VEB of the Russian Federation, if the growth rate of the economy and real disposable incomes of the population double, the share of the poor population with incomes below the subsistence minimum will decrease to $10 \%$ in 2024 and to $7-8 \%$ by $2030 "$ [14].

In the next two years, the global economy will pick up pace and momentum, and by the end of 2021, global GDP will reach a pre-pandemic level. The basic scenario of the forecast provides for a drop in global GDP by $1.4 \%$ in 2020 , followed by a rebound in 2021 against the background of overcoming the main consequences of the coronavirus epidemic and returning to pre-crisis growth rates [21]. After a sharp decline this year, global GDP is projected to grow by about $4 / 4$ percent in 2021 and another 3/4 percent in 2022 [15].

A separate look at China. Despite the above exogenous factors, "China's economic reforms have launched a process of change that is fundamentally transforming Chinese society and politics. From changes in the workplace to the new institutional environment in which firms are located, the current position of the labour force in China marks a radical departure from the past [16].

The Russian Federation is no exception in the global space of institutional transformations.

The model of motivational behavior in such labour processes is carried out "on the basis of changes in professional characteristics, the level of competence, knowledge, and the construction of new value networks. As a rule, institutions change, but not values, which does not lead to a complete transformation of the social and labour system and it remains unbalanced and inefficient" [17]. It is precisely because of the abovementioned motivation of personnel should be carried out "on condition of reproducing the stimulating role of wages for work and increasing its correlation to the achieved level of education" [18].

Labour relations in Germany are characterized by well-organized trade unions and employers' associations that comprehensively regulate working conditions through industry-wide collective bargaining, formalized employee participation in decision-making to limit managerial prerogatives, employment provision, and the development of industry-specific training programs that produce a workforce with high industry and brand skills [19].

According to the pessimistic scenario, the total income of the population will show a strong decline in real terms not only in 2020, but also in 2021.

In figure 1, starting from the period 2016-2020, there is a positive dynamics of growth in the average per capita income of the population. The forecast made for 2020 did not take into account the impact of exogenous factors caused by the COVID-19 virus pandemic. At the same time, the error in forecasting average per capita income was $18.3 \%$.

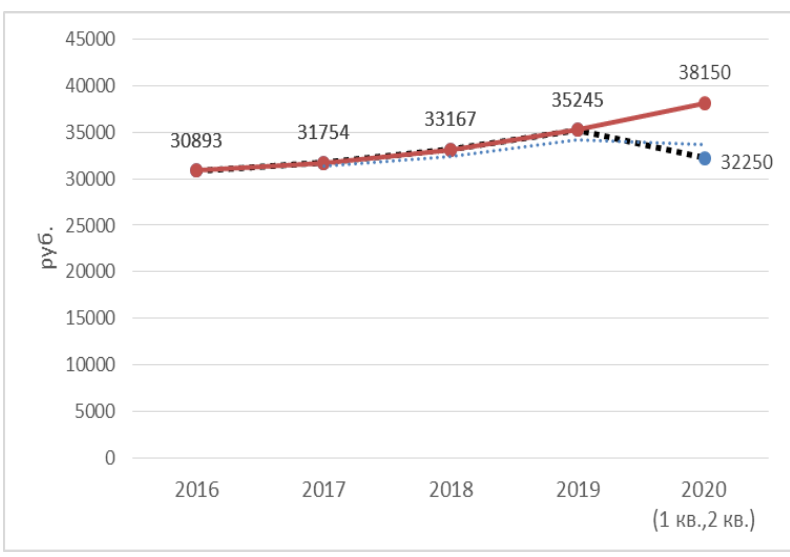

Figure 1 Dynamics of the average per capita monetary income of the population of the Russian Federation for 2016-2020 (the dotted line is the drop in income since the beginning of the COVID-19 pandemic). Source: Rosstat, 2020 [20]. Calculations of the authors.

In table 1 , a correlation and regression analysis is carried out, on the basis of which the empirical regression equation is determined:

$\mathrm{y}=2.0117 \times-20791.8273$

The change in GDP by PPP significantly affects the average per capita income, the correlation coefficient was $r=0.986$, the accuracy of the selection of the regression equation $\mathrm{R}^{2}=0.986^{2}=0.9715$ is high. It is proved that the change in GDP by PPP significantly affects the average per capita income.

Can these forms of employment from an industrial and post-industrial society survive in an accelerated, digitalizing society? How will new forms of digital employment affect traditional labour relations, labour protection and social protection? [23]. 
Table 1. The correlation analysis of GDP by PPP and average per capita income in Russia for 1992-2019 (authors' calculations)

\begin{tabular}{|c|c|c|c|c|c|c|c|c|c|}
\hline \multirow{2}{*}{ Indicators } & \multicolumn{9}{|c|}{ Years } \\
\hline & 1992 & 2000 & 2005 & 2010 & 2015 & 2016 & 2017 & 2018 & 2019 \\
\hline $\begin{array}{l}\text { Per capita } \\
\text { monetary } \\
\text { income of the } \\
\text { population, } \\
\text { RUB (D) }\end{array}$ & $\begin{array}{l}4.017 \\
\text { (before } \\
1998, \text { in } \\
\text { thousan } \\
\text { ds of } \\
\text { rubles) }\end{array}$ & 2,281 & 8,088 & 18,958 & 30,254 & 30,865 & 31,745 & 33,010 & 35,100 \\
\hline $\begin{array}{l}\text { GDP } \\
\text { by PPP per } \\
\text { capita, } \\
\text { (USD) }\end{array}$ & 10,102 & 10,524 & 16,214 & 21,270 & 24,146 & 24,110 & 25,749 & 27,317 & 28,184 \\
\hline \multicolumn{10}{|c|}{$\begin{array}{l}\text { The regression equation (an empirical equation of regression) } \\
y=2.0117 \times-20791.8273\end{array}$} \\
\hline $\begin{array}{l}\text { The correlation } \\
\text { coefficient }\end{array}$ & \multicolumn{9}{|c|}{$\begin{array}{l}r=0,986 \\
\text { (the connection between GDP in PPP terms and determinant } \mathrm{D} \text { is very high and direct) }\end{array}$} \\
\hline $\begin{array}{l}\text { The } \\
\text { significance of } \\
\text { the correlation } \\
\text { coefficient }\end{array}$ & \multicolumn{9}{|c|}{$\begin{array}{l}\text { H0: rxy }=0, \text { no linear connection between variables; } \\
\text { H1: rxy } \neq 0 \text {, there is a linear connection between the variables; } \\
\text { If } \mid t \text { observe } \mid>\text { tcrit }- \text { we reject the null hypothesis. } \\
\text { tobserve }=15,459 \\
\text { Significance level } \alpha=0.05 \text { and degree of freedom } \mathrm{k}=7 \\
\text { tcrit= tcrit }(\mathrm{n}-\mathrm{m}-1 ; \alpha / 2)=2,841(2) \\
\text { Since } \mid \mathrm{t} \text { observe } \mid>\text { tcrit, we reject the hypothesis of equality } 0 \text { for } \mathrm{r} \text {. } \\
\text { The correlation coefficient is statistically significant. }\end{array}$} \\
\hline \multirow{3}{*}{$\begin{array}{l}\text { Coefficient and } \\
\text { criteria }\end{array}$} & \multicolumn{9}{|c|}{ The calculation of the coefficients and criteria of Student and Fischer } \\
\hline & \multicolumn{2}{|c|}{$\begin{array}{l}\text { Coefficient of } \\
\text { determination }\end{array}$} & \multicolumn{2}{|c|}{ Student's Criterion } & \multicolumn{3}{|c|}{ Fisher's Criterion } & \multicolumn{2}{|c|}{$\begin{array}{l}\text { Coefficient } \\
\text { elasticity and } \\
\beta \text {-coefficient }\end{array}$} \\
\hline & $\begin{array}{l}\text { the acc } \\
\text { the } \\
\text { equation } \\
\text { is high }\end{array}$ & $\begin{array}{l}\text { acy of } \\
\text { gression } \\
\text { election }\end{array}$ & \multicolumn{2}{|c|}{$\begin{array}{l}\text { regression } \\
\text { coefficient } b \\
15.46>2.841 \\
2) \text { the regression } \\
\text { coefficient a } \\
7.31>2.841\end{array}$} & $\begin{array}{l}\text { the coefficient of } \\
\text { determination is statistically } \\
\text { significant }\end{array}$ & $\begin{array}{l}\mathrm{F}=238,983 \\
\mathrm{k} 1=1 \text { and } \mathrm{k} 2=7, \text { Ftable }= \\
5.59 \\
\mathrm{~F}>\mathrm{F} \text { table, }\end{array}$ & $\begin{array}{l}\text { Ftable }= \\
\text { of } \\
\text { atistically }\end{array}$ & \multicolumn{2}{|c|}{$\begin{array}{l}\text { the change in GDP } \\
\text { by PPP significantly } \\
\text { affects the average } \\
\text { per capita income } \\
\beta \mathrm{j}=\mathrm{bj}_{\mathrm{j}} \frac{S(x)}{S(y)}=0,986\end{array}$} \\
\hline
\end{tabular}

Some studies show that a $10 \%$ increase in the country's digitalization rate contributes to a $0.75 \%$ increase in GDP per capita [24]. At the same time, the transformation and digitalization of labour relations "over the next 10 years, will allow for a global increase in nominal GDP of USD 4.4 trillion, an additional USD 930 billion in total household income for the poorest and 64 million new jobs" [25]. All this "will lead to the polarization of the labour market and an increase in the share of both high-paid and low-paid workers" [26].

Companies are increasingly looking for a chief digital officer, who can find himself/herself surrounded by other new positions, such as Data miner, Data analyst, Data manager, etc. [27].
If we focus not only on GDP growth, but also on the structure of labour relations, then changes in labour market institutions can also have a significant impact [22]. Digitalization has created endless opportunities for new forms of employment and modes of production that transcend time and space constraints.

\section{RESULTS DISCUSSION}

The scale of transformation processes in the sphere of social and labour relations in connection with epidemiological factors create prerequisites for further digitalization of the economy, taking into account the factors of globalization, integration of companies and technological achievements [28]. 
The transformation of labour relations has become a natural reaction to the imperfection of the modern world order and exogenous shocks. In this regard, governments and companies around the world should focus on providing opportunities for current and future employees to acquire appropriate skills. It is important to ensure the positive dynamics of the impact of robotics and automation on employment, quality of work and the level of wages [29]. In the process of transformation and digitalization of social and labour relations, it is necessary to pay attention to the use of "sensor technologies and the spread of networks" that improve the parameters of production and labour systems [30].

Increasing the pace of economic development through the digitalization of the economy based on the mechanism of "built-in stabilizers" can be a measure that creates both positive and negative effects affecting the polarization of society and social inequality.

\section{CONCLUSION}

The nature of the institutional structure of labour relations is changing, and at the same time there is a growing understanding that wages are adjusted only slowly in the process of cumulative shocks. It is important to take into account external epidemiological shocks, to stabilize them on the basis of institutional transformation of social and labour relations. Doubling the growth rate of the economy and the real disposable income of the population in Russia from $2 \%$ in the basic conservative version to $4 \%$ in the moderately optimistic scenario of accelerated growth will reduce the share of the poor population with incomes below the subsistence minimum. In the next two years, the global economy will gain momentum and by the end of 2021, global GDP will reach a pre-pandemic level. The policy of implementing social support measures and providing jobs, which has been implemented since the beginning of the pandemic, will allow for a faster recovery after the lifting of restrictions, and the growth of the country's digitalization rate by $10 \%$ contributes to an increase in GDP per capita by $0.75 \%$. A direct relationship between GDP at purchasing power parity and household income is established. Already in 2016, it was clear that technology and innovation would help create competitive advantages and increase productivity in various industries and regions. Thus, the transformation of social and labour relations becomes evident in the conditions of increasing influence of digitalization, which, in turn, affects the formation of an effective system for the development of high-income jobs and the stabilization of the Russian economy.

\section{REFERENCES}

[1] J. Horecký, Operation and Action of a Trade Union (in terms of Czech Republic Labour Law), Central
European Journal of Labour Law and Personnel Management 1(1) (2018) 17-27. DOI: https://doi.org/10.33382/cejllpm.2018.01.02

[2] T. Medvedeva, S, Umpleby, A Multidisciplinary View of Social and labour Relations: Changes in Management in the U.S. and Russia as Examples, Cybernetics and Systems 46 (2015) 681-697. DOI: https://doi.org/10.1080/01969722.2015.1082405

[3] The future of work: Trade unions in transformation, International Journal of Labour Research, Vol. 9, Iss. 1-2, 2019.

[4] Sociological research "Methods and technologies of influence on workers for the purpose of involvement in the trade union and formation of conscious membership in the organization". Analytical note, Moscow, June 2012, p. 32 (In Russ.).

[5] K. Kolin, Strategic guidelines in the management of quality of life in modern society, Bulletin of Moscow State university named after S.Yu. Witte, Series 1: Economics and Management 1(32) (2020) 7-15. DOI: https://doi.org/10.21777/2587-554X2020-1-7-15 (In Russ.)

[6] McMillan, John \& Woodruff, Christopher, The Central Role of Entrepreneurs in Transition Economies, Journal of Economic Perspectives 16. (2002) 153-170.

[7] Ana-Maria \& Voda, Ana Iolanda, Labour Relations: Contemporary Issues in Human Resource Management, (2017). DOI: https://doi.org/10.5772/intechopen.68625

[8] "The Great Transformation" by Karl Polanyi: past, present, future. Under the general editorship of R.M. Nureyev, Moscow: Higher School of Economics, 2007 (Series "Conferences of the Department of Economic Theory of the Higher School of Economics"), pp. 23-24 (In Russ.).

[9] I.S. Salikhova, Theoretical analysis of the mechanism of negative impact of socio-economic inequality on the development of the country, Bulletin of Moscow State University named after S.Yu. Witte, Series 1: Economics and Management 2(33) (2020) 15-21. DOI: https://doi.org/10.21777/2587-554X-2020-2-15-21 (In Russ.)

[10] C. Shapiro, J. Stiglitz, 'Equilibrium Unemployment as a Worker Discipline Device', American Economic Review 74(3) (1984) 433-444.

[11] E. Shulzhenko Human resource management and labour relations in post-transitional Russia, 2012, p. 19. 
[12] Proceedings of the Free Economic Society of Russia, Moscow, Iss. 4/2019, p. 331 (In Russ.).

[13] K. Musial, Institutionalisation of Scandinavian Consensual Democracy, Folia Scandinavica Posnaniensia 5 (1999) 59-73.

[14] Proceedings of the Free Economic Society of Russia, Moscow, Iss. 4/2019, p. 106 (In Russ.).

[15] OECD Economic Outlook, Vol. 2020, Iss. 2.

[16] D. Guthrie, The transformation of labour relations in China's emerging market economy, Research in Social Stratification and Mobility 19 (2002) 139170. DOI: https://doi.org/10.1016/S02765624(02)80040-3

[17] E. Legchilina, Transformation of Social and labour Relations: Theory and Methodology, 2020, p. 30. DOI: https://doi.org/10.2991/fred-19.2020.101

[18] A.V. Voronina, Professional training - vector of development of personnel of the organization, Bulletin of Moscow University named after S.Yu. Witte. Series 1: Economics and Management 1(28) (2019) 95-101.

DOI: https://doi.org/10.21777/2587-554X-2019-1-95101 (In Russ.)

[19] B. Keller, Berndt \& Kirsch, Anja. Employment Relations in Germany - ICER 6th ed., 2016, pp. 196-223.

[20] Per capita monetary income of the population, Rosstat, 2020. Retrieved from: https://rosstat.gov.ru (In Russ.)

[21] Scenario forecast of macroeconomic dynamics and incomes of the population until 2024, National Research University Higher School of Economics, 2020, p. 8. Retrieved from: https://dcenter.hse.ru/data/2020/05/20/1548209626 /DC\%20HSE\%20-

\%20forecast_macro_hh_income_2020_04.pdf (In Russ.)

[22] Digitalization and structural labour market problems: The case of Germany, 2016, p. 26. Retrieved from: https://www.ilo.org/wcmsp5/groups/public/dgrepor ts/inst/documents/publication/wcms_522355.pdf

[23] B. Chen, T. Liu, Y. Wang 5, Volatile Fragility: New Employment Forms and Disrupted Employment Protection in the New Economy, International Journal of Environmental Research and Public Health, 2020, pp. 1-14. DOI: https://doi.org/10.3390/ijerph17051531

[24] Digitization for economic growth and job creation, 2013.

Retrieved

from: https://www.strategyand.pwc.com/m1/en/reports/di gitization-for-economic-growth-and-jobcreation.pdf

[25] Digitization for economic growth and job creation, 2012. Retrieved from: https://www.strategyand.pwc.com/m1/en/reports/2 011-2014/digitization-economic-growth-jobcreation.html

[26] M. Arntz, T. Gregory, U. Zierahn, Digitalization and the Future of Work: Macroeconomic Consequences, IZA DP Iss. 12428, 2019. Retrieved from: http://ftp.iza.org/dp12428.pdf

[27] Degryse, Christophe, Digitalisation of the Economy and its Impact on Labour Markets, SSRN Electronic Journal, 2016. DOI: https://doi.org/10.2139/ssrn.2730550

[28] E.Ya. Butko, Human Resource Management, Educational resources and technologies 5(17) (2016) 3-9. DOI: https://doi.org/10.21777 / 23125500-2016-5-3-9 (In Russ.)

[29] M.I. Velaga, V.I. Fedorova, I.S. Bondarenko, Analysis of the international robotics market: state and impact on labour resources, Bulletin of Moscow State University named after S.Yu. Witte, Series 1: Economics and Management 4(27) (2018) 91-98. DOI: https://doi.org/10.21777/2587-554X2018-4-91-98 (In Russ.)

[30] R.A. Perelet, The role of information technologies in the transition to a closed-loop economy, Educational resources and Technologies 3(28) (2019) 74-82. DOI: https://doi.org/10.21777/25002112-2019-3-74-82 (In Russ.) 